CEPHALOSPORINS. VI

SYNTHESIS AND STRUCTURE-ACTIVITY RELATIONSHIPS OF NEW $7 \beta$-[( $Z$ )-2-ALKOXYIMINO-2-(2-AMINOTHIAZOL-4-YL)ACETAMIDO]CEPHALOSPORINS WITH A TETRAZOLOPYRIDAZINE AT THE 3-POSITION

\author{
Marco Alpegiani, Ferruccio Casabuona, Raffaello Giorgi, \\ Giuliano Nannini,* Ettore Perrone, \\ Department of Chemistry \\ Giuseppe Meinardi, Alberta Bianchi and Gisella Monti
}

Department of Biology

Farmitalia-Carlo Erba S.p.A., Research and Development, Via C. Imbonati, 24-20159 Milan, Italy

(Received for publication April 25, 1983)

\begin{abstract}
The synthesis and in vitro activity of $7 \beta-[(Z)$-2-alkoxyimino-2-(2-aminothiazol-4-yl) acetamido]cephalosporins with a tetrazolo[1,5-b]pyridazine at the 3-position are described. These cephalosporins showed excellent activity against Gram-negative bacteria, including $\beta$-lactamase producing strains. The most interesting compound of the series was $7 \beta-[(Z)-2-(2-$ aminothiazol-4-yl)-2-methoxyimino acetamido]-3-(8-carboxytetrazolo[1,5-b]pyridazin-6-yl)thiomethyl-3-cephem-4-carboxylic acid (9, FCE 20485) because of its extraordinarily long half-life and marked in vivo activity.
\end{abstract}

A turning-point in the history of cephalosporins was made with the discovery of cefotaxime ${ }^{1 \sim 3)}$, a compound which for the first time combined outstanding potency against Gram-negative bacteria with good resistance to most $\beta$-lactamases.

Since then several groups, including the authors, have attempted to improve on this basic molecule by modifying the oxyimino group and/or replacing the acetoxy group at the 3-position with different heterocyclic thiols. In particular, because cefotaxime suffered from poor activity against some Grampositive bacteria, and from a relatively short half-life and metabolic inactivation, our goal was to find derivatives provided with a better balanced spectrum of antibacterial activity, and a more favorable pharmacokinetic profile. After a few orientative experiments, we focused our attention on congeners bearing a tetrazolo[1,5-b]pyridazin-6-ylthiomethyl group at the 3-position, a type of substitution we had previously studied in depth and employed with good results, and which had appropriately balanced the overall antimicrobial spectrum of compounds with strongly hydrophilic 7-side chains ${ }^{4}$.

General formula of the products synthesized are shown at the right. Of these, compound 9 $\left(\mathrm{R}_{1}=\mathrm{Me}, \mathrm{R}_{2}=\mathrm{COOH}\right)$, coded FCE 20485, showed prolonged serum half-life and promising therapeutic effectiveness in preliminary in vivo experiments in mice. This paper describes the synthesis of new cephalosporins and the results<smiles></smiles>

$\mathrm{R}_{1}=\mathrm{H}, \mathrm{Me}, \mathrm{Et}, \mathrm{CH}_{2} \mathrm{COOH}, \mathrm{CMe}_{2} \mathrm{COOH}$ $\mathrm{R}_{2}=\mathrm{H}, \mathrm{NH}_{2}, \mathrm{COOH}, \mathrm{CONH}_{2}$ 
Chemistry

The heterobicyclic thiols and 3-heterocyclylthiomethyl derivatives of 7-ACA have been reported in a previous paper ${ }^{4}$. Cephalosporins 1 12 (Table 1) were prepared by conversion of the alkoxyimino acids to the corresponding acyl chlorides followed by coupling with 7-ACA derivatives. The amino group present in the thiazole ring was protected with tritylchloride; the hydroxyl and carboxy group, when present on the imino moiety, were masked respectively as trityl ethers $(4,8)$ and tert-butyl esters $(2,3,6,7$ and 11). Warm aqueous formic acid was usually expedient for the simultaneous removal of all the protecting groups. The oxime syn configuration was preserved throughout the synthesis, as shown by high-field resonance of the thiazole proton in the ${ }^{1} \mathrm{H}$ NMR spectrum ${ }^{2}$.

The cephalosporins synthesized are listed in Table 1. Their purity, established by NMR, TLC and analysis was greater than $90 \%$.

\section{Antimicrobial Activity}

The minimum inhibitory concentration (MIC) of the new compounds against 2 strains of Grampositive and 12 strains of Gram-negative bacteria, including $\beta$-lactamase producing strains, was determined by the standard two fold serial dilution method using diagnostic sensitivity test agar (Oxoid). The plates were inoculated with about $2 \times 10^{5}$ colony forming units using an automatic inoculator (Denley Tech. Ltd). The results reported in Table 2 are the geometric average of two determinations and are compared with cefazolin, cefuroxime and cefotaxime.

All the compounds synthesized are in general markedly more active than cefazolin and cefuroxime against Gram-negative bacteria, showing in addition interesting in vitro activity against Pseudomonas aeruginosa; substituents other than methoxy on the imino group performed noticeably worse. Although in vitro no general improvement over cefotaxime was discernible at first sight, some compounds

Table 1.

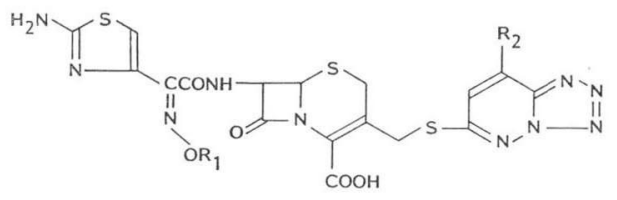

\begin{tabular}{|c|c|c|c|c|c|}
\hline Compound & $\mathrm{R}_{1}$ & $\mathrm{R}_{2}$ & $\begin{array}{c}\text { IR }(\beta \text {-lactam }) \\
\left(\mathrm{cm}^{-1}\right)\end{array}$ & $\begin{array}{c}\text { Thiazole } \\
5-\mathrm{H} \\
(\mathrm{ppm})\end{array}$ & Formulag) \\
\hline 1 & $\mathrm{Me}$ & $\mathrm{H}$ & $1760^{c)}$ & $7.15^{\mathrm{d})}$ & $\mathrm{C}_{18} \mathrm{H}_{16} \mathrm{~N}_{10} \mathrm{O}_{5} \mathrm{~S}_{3}$ \\
\hline 2 & $\mathrm{CH}_{2} \mathrm{COOH}$ & $\mathrm{H}$ & $1775^{c)}$ & $6.80^{\mathrm{d})}$ & $\mathrm{C}_{19} \mathrm{H}_{10} \mathrm{~N}_{10} \mathrm{O}_{7} \mathrm{~S}_{3}$ \\
\hline 3 & $\mathrm{CMe}_{2} \mathrm{COOH}$ & $\mathrm{H}$ & $1780^{\mathrm{b})}$ & $7.05^{f)}$ & $\mathrm{C}_{21} \mathrm{H}_{20} \mathrm{~N}_{10} \mathrm{O}_{7} \mathrm{~S}_{3} \cdot \mathrm{HCl}$ \\
\hline 4 & $\mathrm{H}$ & $\mathrm{NH}_{2}$ & $1760^{\mathrm{a})}$ & $6.76^{\mathrm{d})}$ & $\mathrm{C}_{17} \mathrm{H}_{15} \mathrm{~N}_{11} \mathrm{O}_{5} \mathrm{~S}_{3}$ \\
\hline 5 & $\mathrm{Me}$ & $\mathrm{NH}_{2}$ & $1760^{a)}$ & $6.82^{\mathrm{d})}$ & $\mathrm{C}_{18} \mathrm{H}_{17} \mathrm{~N}_{11} \mathrm{O}_{5} \mathrm{~S}_{3}$ \\
\hline 6 & $\mathrm{CH}_{2} \mathrm{COOH}$ & $\mathrm{NH}_{2}$ & $1770^{c)}$ & $6.82^{\mathrm{d})}$ & $\mathrm{C}_{19} \mathrm{H}_{17} \mathrm{~N}_{11} \mathrm{O}_{7} \mathrm{~S}_{3}$ \\
\hline 7 & $\mathrm{CMe}_{2} \mathrm{COOH}$ & $\mathrm{NH}_{2}$ & $1770^{a)}$ & $6.75^{\mathrm{d})}$ & $\mathrm{C}_{21} \mathrm{H}_{21} \mathrm{~N}_{11} \mathrm{O}_{7} \mathrm{~S}_{3}$ \\
\hline 8 & $\mathrm{H}$ & $\mathrm{COOH}$ & $1760^{a)}$ & $7.59^{\mathrm{e})}$ & $\mathrm{C}_{18} \mathrm{H}_{14} \mathrm{~N}_{10} \mathrm{O}_{7} \mathrm{~S}_{3}$ \\
\hline 9 & $\mathrm{Me}$ & $\mathrm{COOH}$ & $1765^{a)}$ & $6.83^{\mathrm{d})}$ & $\mathrm{C}_{19} \mathrm{H}_{10} \mathrm{~N}_{10} \mathrm{O}_{7} \mathrm{~S}_{3} \cdot 2 \mathrm{H}_{2} \mathrm{O}$ \\
\hline 10 & Et & $\mathrm{COOH}$ & $1775^{a)}$ & $6.82^{\mathrm{d})}$ & $\mathrm{C}_{20} \mathrm{H}_{18} \mathrm{~N}_{10} \mathrm{O}_{7} \mathrm{~S}_{3}$ \\
\hline 11 & $\mathrm{CMe}_{2} \mathrm{COOH}$ & $\mathrm{COOH}$ & $1780^{a)}$ & $7.56^{\mathrm{e})}$ & $\mathrm{C}_{22} \mathrm{H}_{20} \mathrm{~N}_{10} \mathrm{O}_{9} \mathrm{~S}_{3} \cdot \mathrm{HCl}$ \\
\hline 12 & $\mathrm{Me}$ & $\mathrm{CONH}_{2}$ & $1780^{c)}$ & $7.18^{\mathrm{d})}$ & $\mathrm{C}_{18} \mathrm{H}_{17} \mathrm{~N}_{11} \mathrm{O}_{8} \mathrm{~S}_{3}$ \\
\hline
\end{tabular}


Table 2. In vitro antibacterial activity of cephalosporins.

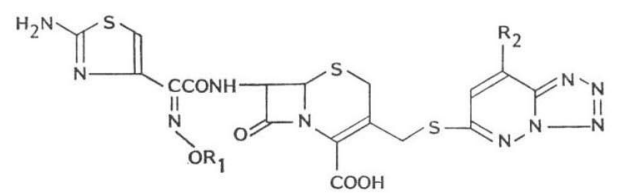

\begin{tabular}{|c|c|c|c|c|c|c|c|c|c|c|c|c|c|c|c|c|}
\hline \multirow[b]{2}{*}{ Compound } & \multirow[b]{2}{*}{$\mathrm{R}_{1}$} & \multirow[b]{2}{*}{$\mathrm{R}_{2}$} & \multicolumn{14}{|c|}{$\operatorname{MIC}(\mu \mathrm{g} / \mathrm{ml})^{\mathrm{a}}$} \\
\hline & & & $\underset{\text { (R) }}{S . a .}$ & S. p. & E. c. & $K . p$. & E.ae. & S. $t$. & S. s. & P. m. & P. v. & E. c.t. & K. ae. & $\begin{array}{l}\text { E. cl. } \\
\text { P } 99\end{array}$ & P. ae. & B. $f r .^{\mathrm{b}}$ \\
\hline 1 & $\mathrm{Me}$ & $\mathrm{H}$ & 0.7 & 0.003 & 0.17 & 0.003 & 0.4 & 0.17 & 0.35 & 0.015 & $\leqq 0.001$ & 0.17 & 22.6 & 22.6 & 8 & 16 \\
\hline 2 & $\mathrm{CH}_{2} \mathrm{COOH}$ & $\mathrm{H}$ & 4 & 0.03 & 0.25 & 0.03 & 0.5 & 0.25 & 1 & 0.002 & 0.003 & 0.35 & 2.8 & 90.5 & 11.3 & 64 \\
\hline 3 & $\mathrm{CMe}_{2} \mathrm{COOH}$ & $\mathrm{H}$ & 2.8 & 0.04 & 0.5 & 0.12 & 1 & 0.35 & 0.5 & 0.008 & $\leqq 0.001$ & 0.71 & 1 & 16 & 8 & 16 \\
\hline 4 & $\mathrm{H}$ & $\mathrm{NH}_{2}$ & 0.5 & $\leqq 0.002$ & 0.25 & 0.004 & 0.5 & 0.12 & 0.5 & 0.015 & 0.008 & 1 & 32 & 32 & 8 & n.t. \\
\hline 5 & $\mathrm{Me}$ & $\mathrm{NH}_{2}$ & 0.5 & 0.002 & 0.25 & 0.004 & 0.5 & 0.12 & 0.25 & 0.015 & 0.001 & 0.25 & 4 & 16 & 4 & n.t. \\
\hline 6 & $\mathrm{CH}_{2} \mathrm{COOH}$ & $\mathrm{NH}_{2}$ & 4 & 0.03 & 0.35 & 0.04 & 0.5 & 0.25 & 0.7 & 0.004 & 0.0005 & 0.35 & 5.7 & 90.5 & 4 & 32 \\
\hline 7 & $\mathrm{CMe}_{2} \mathrm{COOH}$ & $\mathrm{NH}_{2}$ & 1.4 & 0.06 & 0.7 & 0.25 & 1.4 & 0.5 & 0.5 & 0.004 & 0.015 & 0.5 & 1 & 32 & 2.8 & 16 \\
\hline 8 & $\mathrm{H}$ & $\mathrm{COOH}$ & 1 & 0.01 & 0.17 & 0.12 & 0.25 & 0.17 & 0.25 & 0.004 & 0.006 & 4 & 90.5 & $>128$ & 16 & n.t. \\
\hline 9 & $\mathrm{Me}$ & $\mathrm{COOH}$ & 2 & 0.015 & 0.12 & 0.06 & 0.12 & 0.08 & 0.12 & 0.006 & $\leqq 0.0002$ & 0.17 & 32 & 128 & 2.8 & 8 \\
\hline 10 & Et & $\mathrm{COOH}$ & 2 & 0.015 & 0.71 & 0.17 & 0.5 & 0.35 & 0.5 & 0.015 & 0.002 & 0.35 & $>128$ & $>128$ & 4 & 8 \\
\hline 11 & $\mathrm{CMe}_{2} \mathrm{COOH}$ & $\mathrm{COOH}$ & 8 & 0.12 & 2 & 1 & 2 & 1 & 1.4 & 0.008 & $\leqq 0.001$ & 2 & 4 & 64 & 8 & 16 \\
\hline 12 & $\mathrm{Me}$ & $\mathrm{CONH}_{2}$ & 0.5 & 0.004 & 0.25 & 0.01 & 0.25 & 0.12 & 0.35 & 0.03 & 0.001 & 0.17 & 4 & 16 & 8 & 4 \\
\hline \multicolumn{3}{|c|}{ Cefazolin } & 0.57 & 0.06 & 1.4 & 0.7 & 2 & 1.4 & 1.4 & $5.7=$ & $>128$ & 12.5 & $>128$ & $>128$ & $>128$ & $>128$ \\
\hline \multicolumn{3}{|c|}{ Cefuroxime } & 1 & 0.004 & 8 & 0.06 & 8 & 2.4 & 8 & 0.25 & 16 & 8 & $>128$ & $>128$ & $>128$ & $>128$ \\
\hline \multicolumn{3}{|c|}{ Cefotaxime } & 2 & 0.006 & 0.12 & 0.004 & 0.12 & 0.03 & 0.12 & 0.008 & 0.003 & 0.06 & 5.7 & 128 & 4 & 4 \\
\hline
\end{tabular}

a Organisms included in this Table are: S. a. (R), Staphylococcus aureus 39/2 (benzylpenicillin resistant); S. p., Streptococcus pyogenes C 203; E. c., Escherichia coli G; K. p., Klebsiella pneumoniae ATCC 10031; E. ae., Enterobacter aerogenes ATCC 8308; S. t., Salmonella typhi Watson; S. s., Shigella sonnei ATCC 11060; P. m., Proteus mirabilis ATCC 9921; P. v., Proteus vulgaris X 20; E. c.t., Escherichia coli TEM; K. ae., Klebsiella aerogenes 1082 E; E. cl. P 99, Enterobacter cloacae P 99; P. ae., Pseudomonas aeruginosa ATCC 9027; B. fr., Bacteroides fragilis VPI 9032.

b n.t. $=$ not tested. 
were considered worth further study, either because of their more balanced spectrum (in particular, an up to four fold increase of potency against Gram-positive bacteria was observed for 1, 4, 5 and 12), or for the promise $^{5 \sim 7}$ ) of favorable pharmacokinetic properties connected with the presence of a free carboxy group on the heterocyclic moiety (entries $8 \sim 11$ ). Furthermore, two derivatives $(\mathbf{5}, \mathbf{1 2})$ showed useful levels of activity against Enterobacter cloacae P 99, producer of type Ia $\beta$-lactamase. Compounds 1, 5, 9 and 12 were accordingly selected for plasma half-life evaluation in mice.

A single intravenous injection of $50 \mathrm{mg} / \mathrm{kg}$ of each compound was given to $\mathrm{Crl}$ : CD-1 (ICR) BR mice. Groups of 8 mice $(20 \pm 1 \mathrm{~g})$ were used for each sampling time. The antibiotic concentration in serum was measured by an agar well technique on Folic TE medium (Difco), with $5 \%$ added horse serum, using Bacillus pumilus NCTC 8241 as indicator organism. The half-life in serum was calculated by the least squares method in the terminal linear phase of the curve obtained by plotting the logarithms of concentrations against time.

As shown in Table 3 the introduction of a carboxy group in the heterobicyclic ring (compound 9) markedly increased the plasma half-life, while other modifications left it unchanged (5) or even reduced it (12). Compound 9 is without any doubt one of the cephalosporins with more prolonged half-life in mice. Compound $\mathbf{1 2}$ was discarded because of its too short half-life and compounds $\mathbf{1 , 5}$ and $\mathbf{9}$ were compared in vivo with cefazolin, cefuroxime and cefotaxime (Table 4). The compounds were tested in vivo in mice against experimental infections with Streptococcus pyogenes C 203, Escherichia coli $\mathrm{G}$ and Proteus mirabilis ATCC 9921; the most interesting compound 9 was also tested on Haemophilus influenzae 10479 and Salmonella typhi Watson infections.

The method used was as follows: male albino mice IVA: NMRI (SPF), weighing $18 \sim 20 \mathrm{~g}$, were infected intraperitoneally with the bacterial suspension (stored at $-80^{\circ} \mathrm{C}$ and diluted at the moment of use in Brain-Heart infusion broth, with or without gastric mucin depending on the virulence of the strain) in quantities corresponding to the $\mathrm{LD}_{99}$. Treatment was given subcutaneously immediately after infection and three hours later, according to a scheme of complete balanced blocks, administering the drugs randomly ( 2 groups of 6 or 7 mice per dose). The animals were kept under observation for seven days. The medium effective dose $\left(\mathrm{ED}_{50}\right.$ and fiducial limits for $\left.\mathrm{P}=0.95\right)$ were calculated by probit analysis ${ }^{8}$.

Of our compounds, entry 9 proved most active against Gram-negative organisms. It was 7 to 23 times more active than $\mathbf{1}$, from 5 to 35 times more active than $\mathbf{5}$, from 22 to 180 times more active than cefazolin and from 50 to 180 times more active than cefuroxime. It was as active as cefotaxime against E. coli G, P. mirabilis ATCC 9921 and S. typhi Watson; its activity was 6 times that of cefotaxime against $H$. influenzae 10479. Against Streptococcus pyogenes C 203 it was as active as compound $\mathbf{1}$ and cefazolin, but less active than $\mathbf{5}$, cefuroxime and cefotaxime. Further work is in progress to fully evaluate the potentialities of this new long-lasting third generation cephalosporin.

\section{Experimental}

Infrared spectra were recorded on a Perkin-Elmer spectrometer (model 125). The NMR spectra were determined on a Bruker $\mathrm{HX}-90(90 \mathrm{MHz})$ spectrometer; chemical shifts are reported in parts per million $(\delta)$ relative to $\mathrm{Me}_{4} \mathrm{Si}$. Melting points are not corrected and often not accurately reproducible because of extensive decomposition.

$7 \beta$-[( $Z$ )-2-(2-Aminothiazol-4-yl)-2-methoxyiminoacetamido]-3-(8-carboxytetrazolo[1,5-b]pyridazin6-yl)thiomethyl-3-cephem-4-carboxylic Acid Dihydrate (9) 
Table 3. Plasma half-life in mice after i.v. injection of $50 \mathrm{mg} / \mathrm{kg}$.

\begin{tabular}{cc}
\hline Compound & $\mathrm{t}^{1 / 2}$ (minutes) \\
\hline $\mathbf{1}$ & 10 \\
$\mathbf{5}$ & 10 \\
$\mathbf{9}$ & 90 \\
$\mathbf{1 2}$ & 7 \\
Cefazolin & 16 \\
Cefuroxime & 14 \\
Cefotaxime & 14 \\
\hline
\end{tabular}

Table 4. In vivo activity of $\mathbf{1 , 5 , 9}$, cefazolin, cefuroxime and cefotaxime in acute systemic infection in mice.

\begin{tabular}{|c|c|c|c|c|c|c|}
\hline \multirow{2}{*}{ Challenge organism } & \multicolumn{6}{|c|}{$\mathrm{ED}_{50}$ in $\mathrm{mg} / \mathrm{kg}($ Confidence limits for $\mathrm{P}=0.95)$} \\
\hline & 1 & 5 & 9 & Cefazolin & Cefuroxime & Cefotaxime \\
\hline S. pyogenes C 203 & $0.77(0.57 \sim 1.02)$ & $0.15(0.07 \sim 0.33)$ & $0.38(0.32 \sim 0.45)$ & $0.58(0.48 \sim 0.70)$ & $0.04(0.02 \sim 0.07)$ & $0.09(0.056 \sim 0.14)$ \\
\hline E. coli $\mathrm{G}$ & $2.28(1.92 \sim 2.71)$ & $1.82(1.41 \sim 2.36)$ & $0.34(0.29 \sim 0.41)$ & $7.53(6.22 \sim 9.12)$ & $23.6(18.5 \sim 30.8)$ & $0.2(0.12 \sim 0.34)$ \\
\hline P. mirabilis ATCC 9921 & $3.53(2.4 \sim 5.18)$ & $5.23(3.69 \sim 7.40)$ & $0.15(0.05 \sim 0.46)$ & $14.82(12.47 \sim 17.81)$ & $8.95(7.02 \sim 11.4)$ & $0.14(0.04 \sim 0.46)$ \\
\hline H. influenzae 10479 & n.t. & n.t. & $0.06(0.03 \sim 0.09)$ & $11.29(7.6 \sim 15.11)$ & $10.88(7.78 \sim 14.11)$ & $0.36(0.19 \sim 0.68)$ \\
\hline S. typhi Watson & n.t. & n.t. & $0.17(0.13 \sim 0.22)$ & $11.83(8.93 \sim 15.67)$ & $9.0(5.62 \sim 14.4)$ & $0.27(0.14 \sim 0.53)$ \\
\hline
\end{tabular}

n.t. $=$ not tested. 
To a stirred solution of $(Z)$-2-methoxyimino-2-(2-tritylaminothiazol-4-yl)acetic acid $(11.35 \mathrm{~g}$, $0.0256 \mathrm{~mol})$ and triethylamine $(3.61 \mathrm{ml})$ in dry methylene chloride $(200 \mathrm{ml})$, cooled to $0^{\circ} \mathrm{C}$, phosphorus pentachloride $(5.6 \mathrm{~g}, 0.027 \mathrm{~mol})$ was added portionwise. After stirring for 15 minutes at $0^{\circ} \mathrm{C}$ and 1 hour at room temperature, the mixture was evaporated under reduced pressure, taken up with dry benzene and evaporated again to remove any trace of phosphorus oxychloride. This treatment was repeated twice $(2 \times 50 \mathrm{ml})$. The residue was taken up in $50 \mathrm{ml}$ of dry acetone and the separated triethylamine hydrochloride removed by filtration. The acetone solution of the acyl chloride was then dropped into a cold $\left(0^{\circ} \mathrm{C}\right)$, vigorously stirred solution of $7 \beta$-amino-3-(8-carboxytetrazolo[1,5-b]pyridazin-6yl)thiomethyl-3-cephem-4-carboxylic acid $(10 \mathrm{~g}, 0.0232 \mathrm{~mol})$ and $\mathrm{NaHCO}_{3}(15 \mathrm{~g})$ in a mixture of water $(500 \mathrm{ml})$ and acetone $(250 \mathrm{ml})$. After stirring for 30 minutes at $0 \sim 5^{\circ} \mathrm{C}$ and 90 minutes at room temperature, any undissolved matter was filtered off and most of the acetone was removed in vacuo. The resulting aqueous solution was adjusted to $\mathrm{pH} 2.0$ with $8 \% \mathrm{HCl}$ and extracted with ethyl acetate $(3 \times$ $400 \mathrm{ml}$ ). Washing the organic extracts with aqueous $\mathrm{NaCl}$ solution, drying over $\mathrm{Na}_{2} \mathrm{SO}_{4}$ and removal of the solvent yielded a residue, which was triturated with ethyl ether, filtered, washed with fresh ethyl ether and dried to give 7 $\beta-[(Z)$-2-methoxyimino-2-(2-tritylaminothiazol-4-yl)acetamido]-3-(8-carboxytetrazolo[1,5-b]pyridazin-6-yl)thiomethyl-3-cephem-4-carboxylic acid as a white solid. This compound was added portionwise to a stirred warm $\left(55^{\circ} \mathrm{C}\right)$ solution of $50 \%$ aqueous formic acid $(140 \mathrm{ml})$.

After 30 minutes at $55^{\circ} \mathrm{C}$ the solid (triphenylmethanol) was filtered off, the filtrate was evaporated in vacuo and the residue triturated with water to give the crude product. This was dissolved in aqueous $\mathrm{CH}_{3} \mathrm{COONa}$ solution (at $\mathrm{pH}$ 5.2), filtered from any undissolved material and chromatographed on $\mathrm{Al}_{2} \mathrm{O}_{3}$ previously treated with $\mathrm{pH} 5.1$ phosphate buffer. Elution with $\mathrm{pH} 5.4$ phosphate buffer followed by $2 \%$ aqueous $\mathrm{CH}_{3} \mathrm{COONa}$ solution and subsequent acidification of the appropriate fractions with $8 \% \mathrm{HCl}$ gave a solid which was filtered and dried to give $9.1 \mathrm{~g}(60 \%)$ of $9: \mathrm{mp} 255^{\circ} \mathrm{C} \mathrm{(dec.);} \mathrm{TLC} \mathrm{on}$ silica gel gave a single spot with chloroform - methanol - formic acid - water (140:75:20:20), Rf 0.25. IR (KBr): $3500 \sim 2300,1765,1710,1650,1620 \sim 1580,1540 \mathrm{~cm}^{-1}$; NMR (DMSO-d $): \delta 3.68$ $\left(1 \mathrm{H}, \mathrm{d}, 2-\mathrm{CH}_{2}\right), 3.86\left(1 \mathrm{H}, \mathrm{d}, 2-\mathrm{CH}_{2}\right), 3.92\left(3 \mathrm{H}, \mathrm{s}, \mathrm{OCH}_{3}\right), 4.36\left(1 \mathrm{H}, \mathrm{d}, 3-\mathrm{CH}_{2}\right), 4.69\left(1 \mathrm{H}, \mathrm{d}, 3-\mathrm{CH}_{2}\right)$, $5.21(1 \mathrm{H}, \mathrm{d}, 6-\mathrm{H}), 5.85(1 \mathrm{H}, \mathrm{d}-\mathrm{d}, 7-\mathrm{H}), 6.83\left(1 \mathrm{H}, \mathrm{s}, 5-\mathrm{H}\right.$ on thiazole ring), $7.30\left(2 \mathrm{H}\right.$, br-s, $\mathrm{NH}_{2}$ on thiazole ring), $8.02(1 \mathrm{H}, \mathrm{s}, 7-\mathrm{H}$ on pyridazine ring $), 9.38(1 \mathrm{H}, \mathrm{d}, \mathrm{CONH})$.

Anal. Calcd. for $\mathrm{C}_{10} \mathrm{H}_{10} \mathrm{~N}_{10} \mathrm{O}_{7} \mathrm{~S}_{3} \cdot 2 \mathrm{H}_{2} \mathrm{O}$ : C 36.30, H 3.20, N 22.28, $\mathrm{S} 15.30$. Found: C $35.88, \mathrm{H} 3.25$, N 21.75, S 15.05 .

$7 \beta$-[( $Z$ )-2-(2-Aminothiazol-4-yl)-2-hydroxyiminoacetamido]-3-(8-aminotetrazolo[1,5-b]pyridazin-6yl)thiomethyl-3-cephem-4-carboxylic Acid (4)

An acetone solution of ( $Z$ )-2-(2-tritylaminothiazol-4-yl)-2-trityloxyiminoacetyl chloride was prepared from $2.25 \mathrm{~g}(3.5 \mathrm{mmol})$ of the parent $\left.\mathrm{acid}^{2}\right)$, triethylamine $(0.47 \mathrm{ml})$ and phosphorus pentachloride $(0.697 \mathrm{~g})$ following an experimental procedure analogous to that described for preparation of compound 9. The above solution was dropped into a cold $\left(0^{\circ} \mathrm{C}\right)$, vigorously stirred solution of $7 \beta$ amino-3-(8-aminotetrazolo[1,5-b]pyridazin-6-yl)thiomethyl-3-cephem-4-carboxylic acid $(0.76 \mathrm{~g}, 2 \mathrm{mmol})$, triethylamine $(0.562 \mathrm{ml}, 4 \mathrm{mmol})$ and $\mathrm{NaHCO}_{3}(0.281 \mathrm{~g})$ in water $(35 \mathrm{ml})$ and acetone $(25 \mathrm{ml})$. After 30 minutes at $0^{\circ} \mathrm{C}$ and 90 minutes at room temperature, the reaction mixture was poured into ethyl acetate $(350 \mathrm{ml})$, diluted with water $(50 \mathrm{ml})$ and then adjusted to $\mathrm{pH} 2.0$ with $8 \% \mathrm{HCl}$. The organic phase was separated, washed with aqueous $\mathrm{NaCl}$ solution, dried $\left(\mathrm{Na}_{2} \mathrm{SO}_{4}\right)$ and evaporated to dryness. The resulting foam was triturated with ethyl ether to give $1.98 \mathrm{~g}$ of crude $7 \beta-[(Z)-2$-(2-tritylaminothiazol - 4 -yl) - 2 - trityloxyiminoacetamido] - 3 - (8 - aminotetrazolo [1,5-b] pyridazin- 6 - yl) thiomethyl - 3 cephem-4-carboxylic acid, contaminated by a considerable amount of the starting acid, which could in part be removed by dissolving the mixture in dioxane $(10 \mathrm{ml})$ and dropping the resulting solution into ethyl ether $(70 \mathrm{ml})$. The purified intermediate $(1 \mathrm{~g})$ was added under stirring to a $50 \%$ aqueous formic acid solution $(40 \mathrm{ml}) \mathrm{kept}$ at $55^{\circ} \mathrm{C}$ (oil bath). After 35 minutes the mixture was cooled to $25^{\circ} \mathrm{C}$ and filtered; the solid was washed with fresh $50 \%$ formic acid $(20 \mathrm{ml})$ and then with distilled water and discarded. The acidic solutions were combined and evaporated under reduced pressure. The residue was taken up in $99 \%$ ethanol, evaporated to a small volume $(5 \mathrm{ml})$ and filtered.

The resulting powder was dissolved in $2 \%$ aqueous $\mathrm{NaHCO}_{3}$ solution $(20 \mathrm{ml})$, charcoal was added, and the filtered solution was adjusted to $\mathrm{pH} 2.0$ with $2 \mathrm{~N} \mathrm{HCl}$. After 5 minutes stirring, the precipitate 
was collected by filtration, washed in sequence with water and a small amount of ethanol, and dried at $65^{\circ} \mathrm{C}$ for 16 hours, to give $0.25 \mathrm{~g}$ of $4 ; \mathrm{mp} 205^{\circ} \mathrm{C}$ (dec.). TLC on silica gel gave a single spot with chloroform - methanol - formic acid (160: 70: 30), Rf 0.36. IR (KBr): 3400, 3000, $1760 \mathrm{~cm}^{-1}$; NMR (DMSO$\left.d_{6}\right): \delta 3.61\left(1 \mathrm{H}, \mathrm{d}, 2-\mathrm{CH}_{2}\right), 3.89\left(1 \mathrm{H}, \mathrm{d}, 2-\mathrm{CH}_{2}\right), 4.16\left(1 \mathrm{H}, \mathrm{d}, 3-\mathrm{CH}_{2}\right), 4.60\left(1 \mathrm{H}, \mathrm{d}, 3-\mathrm{CH}_{2}\right), 5.21(1 \mathrm{H}, \mathrm{d}$, 6-H), $5.86(1 \mathrm{H}, \mathrm{d}-\mathrm{d}, 7-\mathrm{H}), 6.42(1 \mathrm{H}, \mathrm{s}, 7-\mathrm{H}$ on pyridazine ring), $6.76(1 \mathrm{H}, \mathrm{s}, 5-\mathrm{H}$ on thiazole ring), $7.20\left(2 \mathrm{H}, \mathrm{br}-\mathrm{s}, \mathrm{NH}_{2}\right.$ on thiazole ring), $8.02\left(2 \mathrm{H}, \mathrm{br}-\mathrm{s}, \mathrm{NH}_{2}\right.$ on pyridazine ring $), 9.56(1 \mathrm{H}, \mathrm{d}, \mathrm{CONH})$, $11.66(1 \mathrm{H}, \mathrm{br}-\mathrm{s}, \mathrm{OH})$.

Anal. Calcd. for $\mathrm{C}_{17} \mathrm{H}_{15} \mathrm{~N}_{11} \mathrm{O}_{5} \mathrm{~S}_{3}:$ C 37.15, H 2.75, N 28.03, S 17.20.

Found:

C $36.81, \mathrm{H} 2.83, \mathrm{~N} 27.73, \mathrm{~S} 16.92$.

$7 \beta-[(Z)-2-(2-A m i n o t h i a z o l-4-y 1)-2$-(2-carboxy-2-propoxyimino)acetamido]-3-(8-carboxytetrazolo[1,5-b]pyridazin-6-yl)thiomethyl-3-cephem-4-carboxylic Acid, Hydrochloride (11)

Starting from ( $Z$ )-2-(2-tert-butoxycarbonyl-2-propoxyimino)-2-(2-tritylaminothiazol-4-yl)acetic acid $^{2)}$ and $7 \beta$-amino-3-(8-carboxytetrazolo[1,5-b]pyridazin-6-yl)thiomethyl-3-cephem-4-carboxylic acid, and following the procedure described for the preparation of $4,7 \beta-[(Z)-2-(2$-tert-butoxycarbonyl-2propoxyimino)-2-(2-tritylaminothiazol-4-yl)acetamido]-3-(8-carboxytetrazolo[1,5-b]pyridazin-6-yl)thiomethyl-3-cephem-4-carboxylic acid was obtained as a white powder $(65 \%)$.

An ice-cold solution of this compound $(1.5 \mathrm{~g})$ in $99 \%$ formic acid $(7 \mathrm{ml})$ and $37 \%$ hydrochloric acid $(0.4 \mathrm{ml})$ was stirred for 1 hour at $0^{\circ} \mathrm{C}$ and 20 minutes at room temperature. The precipitate was removed by filtration and isopropyl ether was added to the solution. The separated amorphous solid was collected and taken up in dry ethanol $(20 \mathrm{ml})$. After stirring for 20 minutes at room temperature, ethyl ether $(20 \mathrm{ml})$ was added, causing the precipitation of a brownish portion which was discarded. The filtrate was diluted with isopropyl ether $(70 \mathrm{ml})$; the white precipitate was filtered, washed with isopropyl ether and dried in vacuo to give $0.62 \mathrm{~g}(57 \%)$ of $11, \mathrm{mp} 200^{\circ} \mathrm{C}(\mathrm{dec}$.). TLC on silica gel gave a single spot with chloroform - methanol - formic acid - water (140: 75:20:20), Rf 0.20. IR (KBr): $3600 \sim 3200,3000 \sim 2400,1780,1725,1675,1630,1540,1445 \sim 1360,1260 \sim 1170,790 \mathrm{~cm}^{-1}$; NMR $\left(\mathrm{CF}_{3} \mathrm{COOH}-d\right): \delta 1.87\left(6 \mathrm{H}, \mathrm{s}, \mathrm{Me}_{2}\right), 4.01\left(2 \mathrm{H}, \mathrm{ABq}, 2-\mathrm{CH}_{2}\right), 4.78\left(2 \mathrm{H}, \mathrm{ABq}, 3-\mathrm{CH}_{2}\right), 5.40(1 \mathrm{H}, \mathrm{d}, 6-\mathrm{H})$, $6.13(1 \mathrm{H}, \mathrm{d}, 7-\mathrm{H}), 7.56(1 \mathrm{H}, \mathrm{s}, 5-\mathrm{H}$ on thiazole ring), $8.39(1 \mathrm{H}, \mathrm{s}, 7-\mathrm{H}$ on pyridazine ring).

Anal. Calcd. for $\mathrm{C}_{22} \mathrm{H}_{20} \mathrm{~N}_{10} \mathrm{O}_{9} \mathrm{~S}_{3} \cdot \mathrm{HCl}$ : C 37.69, $\mathrm{H} 3.02, \mathrm{~N} 19.98, \mathrm{Cl} 5.06, \mathrm{~S} 13.72$. Found:

C 37.23, H 3.15, N 19.78, Cl 4.87, S 13.41 .

\section{References}

1) Bucourt, R.; R. Heymès, A. Lutz, L. Pénasse \& J. Perronnet: Propriétés antibiotiques inattendues dans le domaines des céphalosporines. C.R. Acad. Sc. Paris, Série D, 284: 1847 1849, 1977

2) Bucourt, R.; R. Heymés, A. Lutz, L. Pénasse \& J. Perronnet: Cephalosporines a chaines amino-2thiazolyl-4-acetyles. Influence de la presence et de la configuration d'un groupe oxyimino sur l'activitè antibacterienne. Tetrahedron 34: 2233 2243, 1976

3) Heymés, R.; A. LutZ \& E. Schrinner: Experimental evaluation of HR 756, a new cephalosporin derivative. Pre-clinical study. Infection 5: 259 260, 1977

4) Nannini, G.; E. Perrone, D. Severino, F. Casabuona, A. Bedeschi, F. Buzzetti, P. N. Giraldi, G. Meinardi, G. Monti, A. Ceriani \& I. de Carneri: Cephalosporins. III. Synthesis and structure-activity relationships of 7-vinylenethioacetamido cephalosporins with a tetrazolo-pyridazine at the 3-position. J. Antibiotics 34: 1456 1468, 1981

5) Nannini, G.; G. Molgora, G. Biasoli, P. Cozzi, F. Casabuona, G. Galli, D. Severino, L. Sala, C. Confalonieri, P. N. Giraldi, G. Vita, I. de Carneri, G. Meinardi, G. Monti \& A. Bianchi: New broad-spectrum alkylthio cephalosporins. Arzneim. Forschung 27: 343 352, 1977

6) Nannini, G.; E. Perrone, D. Severino, A. Bedeschi, G. Biasoli, G. Meinardi \& A. Bianchi: Cephalosporins. II. Synthesis and structure-activity relationships of new 7-vinylenethioacetamido and thioacrylamido cephalosporins. J. Antibiotics 34: 412 416, 1981

7) Webbern, J. A. \& W. J. Wheeler: Chemistry and Biology of $\beta$-Lactam Antibiotics. Vol. 1, R. B. Morin \& M. Gorman Ed., pp. 414, Academic Press, 1982

8) Finney, D. J.: Probit Analysis. II. Ed., pp. 20 47; pp. 65 87, Cambridge University Press, 1969

9) O’Callaghan, C. H.; D. G. H. Livermore \& C. E. Newall: 7-Thiazolylacetamido-3-pyridiniummethyl cephalosporin derivatives. Belg. Patent 876,538 